IJ§ER

ISSN: 2149-5939
International Journal of Social Sciences and Education Research

Online, http://dergipark.gov.tr/ijsser

Volume: 1(2), 2015

\title{
Akademik Erteleme Davranışı Ölçeği: Geçerlilik ve güvenirlilik çalışması
}

\author{
The Scale of Academic Procrastination: Validity and reliability study
}

Gürbüz Ocak¹ Ramazan Bulut²

\begin{abstract}
Received Date: $01 / 02$ / 2015
Accepted Date: $01 / 04$ / 2015

$\ddot{O} z$

Akademik hayatta öğrencilere verilen görevlere ilişkin tutumlar, bireylerin o görevleri yapmalarına veya ertelemelerine neden olabilmektedir. Öğrencilerin verilen akademik görevleri ertelemelerini etkileyen çeşitli faktörler vardır. Bu faktörlerin ortaya çıkarılabilmesi amacıyla ilgili çalışmalar göz önünde bulundurularak akademik erteleme davranışını etkileyen faktörleri içeren bir ölçme aracının geliş̧tirilmesi amaçlanmıştır. Araştırmada, genel tarama modeli kullanılmıştır. Araştırmanın çalışma grubunu, 381 öğretmen adayı oluşturmaktadır. Yapılan analizler sonucunda geliştirilen ölçeğin dört faktörden oluştuğu saptanmıştır. 38 maddeden oluşan ölçeğin, birinci faktör ü 19, ikinci faktörü 10, üçüncü faktörü 5 ve dördüncü faktörü 4 maddeden oluşmaktadir. Ölçeğin alt faktörleri için madde toplam korelâsyonları I. faktör için .803 - .526; II. faktör için 677- .492; III. faktör için .678- .502; IV. faktör için ise .481-.378 arasinda değişmektedir. Ölçeğin toplam alfa katsayı değeri $\alpha=0.947$; alt faktörlerde ise bu değer $\alpha=, 951-, 640$ arasinda değişmektedir.
\end{abstract}

Anahtar sözcükler: Akademik erteleme davranışı, öğretmen adayları, ölçek geliştirme

\begin{abstract}
In academic life, students' attitudes towards the duties may cause them to fulfil these duties or delay them. There are various factors which cause students to delay these academic duties. It is aimed to develop a scale which includes these factors which effect the academic delay behaviour by taking into consideration the related studies in order to find out these factors. In this research, general survey model has been used. The study population of this research includes 381 candidate teachers. It has been determined that the scale which was developed has four factors as a result of analyses. The scale, which has 38 items, is composed of first factor with 19 items, second factor with 10 items, third factor with 5 items and fourth factor with 4 items. Item-total correlation for the I. Factor is between $803-.526$; for the II. Factor is between .677-.492, for the III. Factor is between . 678- .502 and for the IV. Factor is between . 481-.378. The total Alpha coefficient value of the scale is $\alpha=0.947$ and for the subfactors, this value changes between $\alpha=, 951$ and ,640.
\end{abstract}

Keywords: Behaviour towards academic delay, candidate teachers, scale development

\section{Giriş}

Günlük hayatta ertelemek sözcügü Türkçede "sonraya bırakmak, tehir veya tecil etmek" anlamlarında kullanılmaktadır (TDK, 2011: 813). İngilizce sözlükte ise erteleme, "işleri geciktirme veya sonraya bırakma davranışı” anlamında kullanılmaktadır (Stevenson, 2013).

Akademik çalışmalarda ise, erteleme sözcüğü sözlük anlamından ve günlük hayattaki kullanımından farklılaşarak daha farklı anlamlara kavuşmaktadır. Örneğin Tuckman (1991:474), erteleme davranışını "öz performans düzenleme yokluğu” ya da "bireyin kendi isteğiyle görevi yerine getirmeyi geciktirme veya görevden tamamen kaçınma eğilimi” şeklinde tanımlamaktadır (akt: Kennedy \& Tuckman, 2013: 438). Farklı bir tanımda ise erteleme davranışı, bireyin kötü zaman

\footnotetext{
${ }^{1}$ Afyon Kocatepe University, Faculty of Education, AFYONKARAHISAR/TURKEY
}

${ }^{2}$ Afyon Kocatepe University, Faculty of Education, AFYONKARAHISAR/TURKEY 
Ocak, G., Bulut, R. (2015). The Scale of Academic Procrastination: Validity and reliability study. International

Journal of Social Sciences and Education Research, 1 (2), 584-598.

yönetimi ve tembelliğinin yanı sıra güdülenme eksikliğinden dolayı bireyin verilen bir işi ya da görevi zamanında yapmaması olarak tanımlanmaktadır (Senecal, Koestner \& Vallerand, 1995). Yapılan tanımda görüldüğü gibi erteleme davranışı kötü zaman yönetimi ve motivasyon ile ilişkilendirilmiştir.

Araştırmacılar, tutumda olduğu gibi erteleme davranışını da bilişsel, duyuşsal ve davranışsal olmak üzere üç boyutta ele almışlardır. Erteleme davranışının bilişsel boyutu, davranış ile göreve ilişkin niyet veya amaç arasında sürekli olarak (kronik düzeyinde) bir çelişkinin olması şeklinde ifade edilirken, ertelemenin davranışsal boyutu ise "belli bir zaman içinde yapılması gereken işi, oyalanma davranışlarıyla birlikte, başlatmayı, sürdürmeyi ya da tamamlamayı alışkanlık olarak geciktirme eğilimi olarak" olarak tanımlanmaktadır (Çakıcı, 2003;7). Son olarak ertelemenin duyuşsal boyutu ise, bireylerde erteleme davranışının sonuçlarından dolayı meydana gelen duygusal tepkilere atıfta bulunduğu ifade edilmektedir (Binder, 2000).

Erteleme davranışının tanımlarında olduğu gibi sınıflandırılmasında da bir birlik sağlanamamıştır. Chun \& Choi (2005)'ye göre erteleme davranışı, "aktif erteleme ve pasif erteleme" olmak üzere ikiye ayrılmaktadır. Başka bir sınıflandırmada erteleme davranışı beş başlık alıında incelenmiştir:

1- Kompulsif ya da işlevsel olmayan erteleme,

2- Karar vermeyi erteleme,

3- Nevrotik erteleme,

4- Genel erteleme ve son olarak

5- Akademik erteleme eğilimidir (Balkıs, 2007).

Diğer bir sınıflandırmada ise erteleme davranışı, "durumsal erteleme ve kişilik özelliği olarak erteleme" davranışı olarak ikiye ayrılarak incelenmiştir (Vestervelt, 2000). Bu sınıflandırmaya göre araştırmanın da konusunu oluşturan akademik erteleme davranışı, durumsal ertelemenin bir alt türü olarak ele alınmıştır (Ferrari \& Pcyhyl, 2000; Vestervelt, 2000).

Öğrencileri akademik açıdan olumsuz etkileyen (ders veya sınıf tekrarı, düşük akademik başarı vb.) akademik erteleme davranışı, araştırmacılar tarafından ele alınmış olmakla birlikte bu alanla ilgili yapılan her yeni çalışma, akademik erteleme davranışının yapısı ve nedenleri hakkında daha detaylı bilgilerin açığa çıkmasına katkıda bulunmaktadır. İlgili literatür incelendiğinde, akademik erteleme davranışı ile ilgili yeni kuramsal gelişmeleri de içerecek bir veri toplama aracının geliştirilmediği göze çarpmaktadır. Bu nedenle araştırmada, alandaki bu eksikliği azaltabilmek amacıyla ilgili literatür taranarak akademik erteleme davranışı ile ilgili farklı boyutları içeren bir ölçme aracının geliştirilmesi amaç edinilmiştir.

\section{2-Yöntem}

Bireylerin akademik erteleme davranışını ölçmede kullanılabilecek bir ölçek geliştirmeyi amaçlayan bu araştırmada, genel tarama modeli kullanılmıştır. Genel tarama modellerinde amaç, araştırmaya konu olan olay, kişi ve nesneleri hiçbir müdahalede bulunmaksızın olduğu gibi betimlemeye çalışmaktır (Karasar, 2013). 
Ocak, G., Bulut, R. (2015). Akademik Erteleme Davranışı Ölçeği: Geçerlilik ve güvenirlilik çalışması. International Journal of Social Sciences and Education Research, 1 (2), 584-598.

\section{1.Çalışma grubu}

Araştırmanın çalışma grubunu, 2014-2015 eğitim ve öğretim yılı güz döneminde Afyon Kocatepe Üniversitesi Eğitim Fakültesi'nde Sosyal Bilgiler Öğretmenliği, Sınıf Öğretmenliği ve Okulöncesi Öğretmenliği Anabilim Dallarında öğrenim gören öğretmen adayları oluşturmaktadır. Stevens (1996)' a göre deneme aşamasında geliştirilen ölçeğin, madde sayısının en az beş katı kadar büyüklükte bir örneklem grubuna uygulanması gerekmektedir (akt: Erkuş, 2014). Bu nedenle geliştirilen ölçek, belirtilen alanlarda öğrenim gören toplam 397 öğretmen adayına uygulanmıştır. Yönergeye uygun bir şekilde doldurulmayan 12 öğretmen adayının ölçeği değerlendirme dışında tutulmuştur. Bu nedenle analizler 381 öğretmen adayından elde edilen veriler üzerinde yapılmıştır. Araştırmaya katılan öğretmen adaylarından 261 (\%68,5)'i kız, $120(\% 31,5)$ 'si ise erkektir. Araştırmaya her sınıf düzeyinden öğretmen adayları dâhil edilmiştir.

\section{2.Ölçme aracının geliş̧tirilmesi}

Öğretmen adaylarının akademik erteleme davranışlarını ölçmek amacıyla geliştirilen bu ölçek, 5'li likert tipindedir. Bu tip ölçekler, cevaplayıcıların herhangi bir konu ile ilgili yargıları ne derecede onaylayıp onaylamadığını ortaya çıkarmada kullanılır (Karagöz ve Ekici, 2004). Bireylerin kendileri hakkında bilgi verme esasına dayanan likert tipi ölçeklerde bireyler, ölçekte yer alan maddelere ne ölçüde katılıp katılmadıklarını daha önceden belirlenmiş dereceler arasında tercih etmektedirler (Tavşanc1l, 2010). Ölçeğin maddelerine verilen tepkiler hiç katılmıyorum seçeneğinden tamamen katılıyorum seçeneğine doğru beş dereceden oluşmaktadır. Likert tipi bir ölçekten puanların elde edilebilmesi için her maddenin puanlarının toplanması gerekmektedir (Tekindal, 2009). Likert tipi bir ölçeğin geliştirilebilmesi için aşamalı olarak bir dizi işlemlerin yapılması gerekmektedir. Bu işlemler, geliştirilen ölçek kapsamında aşağıda verilmiştir.

\subsubsection{Madde havuzunun oluşturulması}

Madde havuzunun oluşturulabilmesi için öncelikle akademik erteleme davranışı ile ilgili yapılmış olan çalışmalar ve Çakıcı (2003) tarafından geliştirilen "Akademik Erteleme Ölçeği”, Alay ve Koçak (2002) tarafından Türkçeye uyarlanan “Zaman Yönetimi Envanteri” ve Özbay ve M1sırl1-Taşdemir (2003) tarafından Türkçeye uyarlanan "Çok Boyutlu Mükemmeliyetçilik Ölçeği”" incelenmiştir. Bir sonraki aşamada, ölçeğin uygulanacağı öğretmen adaylarıyla benzer özellikleri taşıyan sekiz öğretmen adayına akademik erteleme davranışı ile ilgili dört açık uçlu soru yöneltilmiştir. Bu sorular: "Akademik erteleme davranışı göstermenizin sebepleri nelerdir, Derslerin sıkıcı, ilgi çekici veya kolay-zor olması akademik erteleme davranışınızı nasıl etkilemektedir, Başarısızlık korkusu akademik erteleme davranışınız üzerinde nasıl bir etkiye sahiptir, Zaman yönetim beceriniz, ders çalışma alışkanlığınızı olumlu-olumsuz nasıl etkilemektedir?". Öğretmen adaylarına yöneltilen sorular doğrultusunda elde edilen cevaplar ve yapılan literatür taramasından elde edilen sonuçlara dayalı olarak anahtar kavramlar oluşturulmuş ve bu anahtar kavramlar çerçevesinde madde yazımına başlanarak madde havuzu oluşturulmuştur. Madde havuzunda, akademik erteleme davranışını yansıttığı düşünülen 27' si olumsuz, 52' si olumlu olmak üzere 79 madde yer almaktadır.

\subsubsection{Uzman görüşünün alınması}

Ölçme araçlarında aranan üç nitelikten bir tanesi olan geçerlilik, bir ölçme aracının ölçmek istediği bir özelliği farklı bir özellikle karıştırmadan doğru bir şekilde ölçebilme derecesi olarak 
Ocak, G., Bulut, R. (2015). The Scale of Academic Procrastination: Validity and reliability study. International

Journal of Social Sciences and Education Research, 1 (2), 584-598.

tanımlanmaktadır (Temel, 2010). Bir ölçeğin geçerlilik özelliğini taşıyabilmesinin koşullarından biri, kapsam geçerliliğini sağlamaktır. Kapsam geçerliliği, bir ölçekte yer alan maddelerin ölçülmek istenen özelliği nitelik ve nicelik açısından ne derecede iyi yansıttığıyla ilgilidir (Büyüköztürk, 2012; Ellez, 2012). Kapsam geçerliliğini sağlanmanın yollarından biri, uzman görüşüne başvurmaktır (Tavşancıl, 2010). Bu araştırmada da ölçekte yer alan maddelerin, nitelik ve nicelik açısından ölçülmek istenen özelliği yansıtıp yansıtmadığını belirleyebilmek amacıyla uzman görüşüne başvurulmuştur.

Madde havuzunda yer alan 79 madde bir eğitim bilimleri öğretim üyesine, iki psikolojik danışma ve rehberlik öğretim üyesine ve ilköğretim bölümünde uzman olan bir öğretim üyesine incelettirilmiştir. Uzman görüşleri doğrultusunda kapsam geçerliliğinin sağlanabilmesi amaciyla madde havuzuna dokuz yeni madde eklenmiştir. Yine uzman görüşleri doğrultusunda, birbirine çok benzer olduğu gerekçesiyle sekiz madde çıkarılmıştır. Ayrıca uzman görüşlerinden elde edilen dönütlere göre, ölçekte yer alan maddeler üzerinde dil ve anlatım açısından bazı düzeltmeler yapılmıştır. Yapılan ekleme ve çıkarmalar sonucunda madde havuzunda toplam 80 madde kalmiştır.

\subsubsection{Uygulama aşaması}

Uzman görüşlerinin alınmasının ardından, elde kalan 80 maddeden taslak bir ölçek oluşturulmuştur. Taslak ölçek, çalışma gurubuyla benzer özelliklere sahip olan 14 kişiye uygulanmıştır. Uygulama esnasında ve sonrasında öğretmen adaylarından alınan geri dönütlere göre, ölçekten beş madde çıkarılarak deneme ölçeğine son şekli verilmiştir. Gerekli düzeltmelerden sonra elde kalan 75 maddelik deneme ölçeği, Afyon Kocatepe Üniversitesi Eğitim Fakültesinde öğrenim görmekte olan sosyal bilgiler, okulöncesi ve sınıf öğretmenliği öğrencilerinde uygulanmıştır. Araştırmaya, toplam 397 öğretmen adayı katılmış olup bunlardan 12'sinin kâğıtları değerlendirme dişında tutulduğu için veri analizleri toplam 381 öğretmen adayından elde edilen veriler üzerinde yapılmıştır. Elde edilen verilerin istatistiksel analizleri, bilgisayar ortamında yapılmıştır.

\subsubsection{Faktör analizi}

Ölçeğin yapı geçerliliğinin belirlenebilmesi amacıyla faktör analizi yapılmıştır. Faktör analizi, aynı özelliği ölçmeyi amaçlayan değişkenlerin bir araya getirilerek az sayıda faktör ile açıklanmasını sağlayan istatistiksel bir tekniktir (Büyüköztürk, 2012).

Büyüköztürk (2012), bir ölçekte farklı faktörlerde yer alan maddelerin en yüksek ilk iki yük değerlerinin arasındaki farkın en az .10 olmasının önerildiğini ve birden fazla faktörde yüksek yük veren binişik maddelerin ölçekten çıkarılmasının uygun olduğunu belirtmektedir. Verilerin faktör analizine uygunluğunu belirlemek için yapılan ön analizler sonucunda; KMO Kaiser-Meyer-Olkin (Örneklem Oluşturma Uygunluğu Ölçümü) değeri ,927 ve Barlett testi (Bartlett Bütünlük Testi) sonucu anlamlı [ $p=, 00$ olarak bulunmuştur $(\mathrm{p}<.05)]$. Faktör analizi esnasında, çıkarılan maddelerden sonra KMO değeri .932' ye yükselmiştir.

Araştırmada açımlayıcı faktör analizi ile 75 maddeden oluşan ölçeğin tek ya da çok faktörlü olup olmadığı saptanmaya çalışılmıştır. Ölçeğin faktör sayısının bilinmemesi, başka bir ifade ile maddeler arasındaki ilişkiden hareketle faktörler oluşturarak, ölçeğin faktör yapısı hakkında bilgi sahibi olmak amacıyla açımlayıcı faktör analizi kullanılmıştır (Tavşancıl, 2010). 75 madde üzerinde faktör analizi tekniklerinden biri olan temel bileşenler analizi (Principal Component Analiz) 
Ocak, G., Bulut, R. (2015). Akademik Erteleme Davranışı Ölçeği: Geçerlilik ve güvenirlilik çalışması. International Journal of Social Sciences and Education Research, 1 (2), 584-598.

uygulanmış olup toplam 15 faktör elde edilmiş̧ir. Temel bileşenler analiz tekniği, ölçekteki değişkenler arasında bağımlılık yapısını yok etmek ve boyut indirgemek amacıyla kullanılmıştır (Polat, 2012). Bulunan 15 faktör toplam varyansın \%66,75'ini açıklamaktadır. Faktör analizi kapsamında, elde edilen faktörlerin bağımsızlık, açılık ve anlamlılıkların sağlanabilmesi için döndürme tekniğine başvurulmuştur (Büyüköztürk, 2002). Faktörlerin kendi arasında bağımsız, yani faktörler arasında ilişki olmadığı düşüncesiyle dik döndürme tekniğinin (Saraçl1, 2011) bir alt türü olan varimax rotasyon tekniği kullanılmıştır. Varimax rotasyon tekniğinin kullanılmasının nedeni, ölçeğin birden fazla faktöre sahip olmasıdır (Büyüköztürk, 2002). Faktör yüklerinin alt kesim noktası olarak 0,40 faktör yüküne sahip maddeler işleme alınmış ve 0,40 'tan düşük faktör yüküne sahip maddeler işleme alınmamıştır (Büyüköztürk, 2012).

Tablo 1. Akademik Erteleme Davranışı Ölçeğinin çizgi grafiği

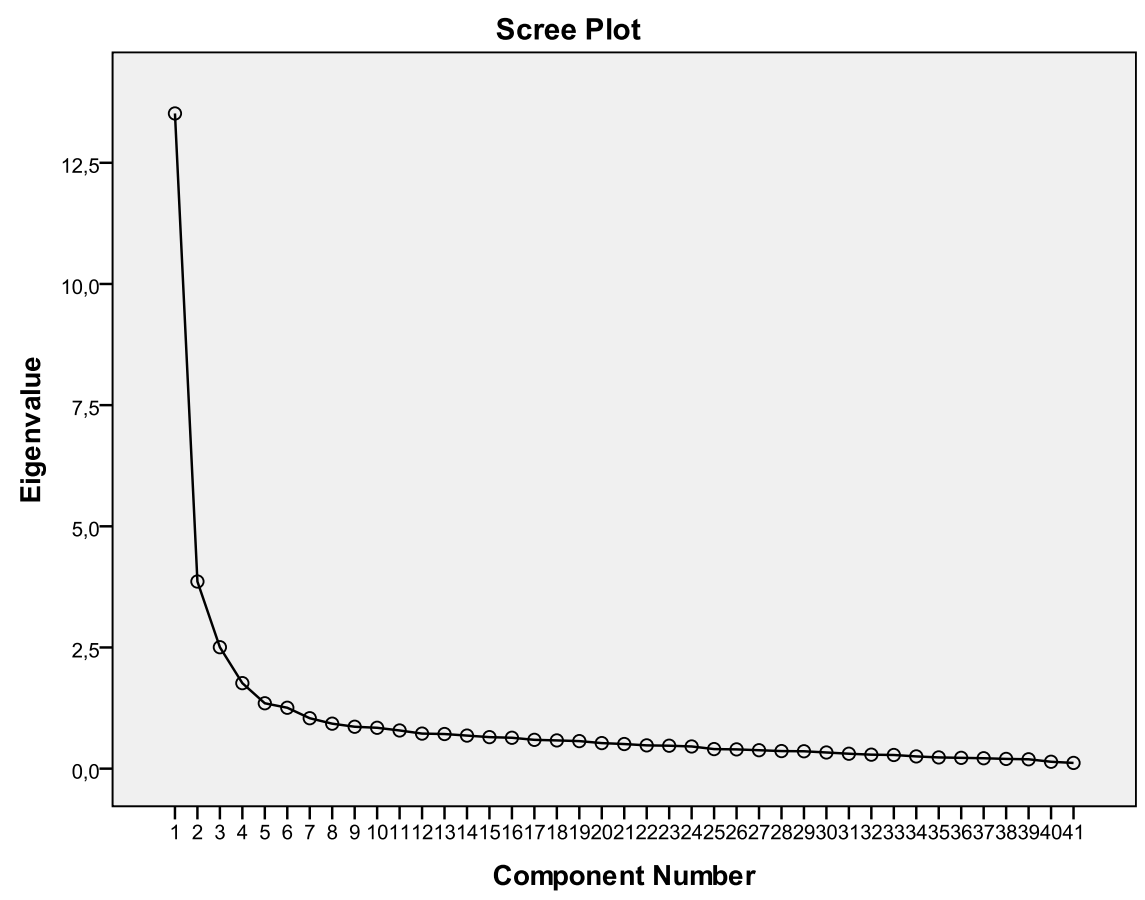

Döndürülmüş bileşenler matris tablosu verilerine göre, ölçekteki bazı maddelerin birden fazla faktöre yüklendiği ve bazı maddelerin faktör yüklerinin düşük olduğu belirlenmiştir. Bu maddeler, faktör sayısını sınırlandırmak ve güvenirlik düzeyini yükseltmek için ölçme aracından çıkarılmıştır. Yapılan analizler sonucunda, yukarıda belirtilen kriterler doğrultusunda 34 madde ölçekten çıkarılmıştır. Maddeler ölçekten elendikten sonra tekrar faktör analizine başvuruldu ve sonuç olarak 8 faktör elde edildi. 
Ocak, G., Bulut, R. (2015). The Scale of Academic Procrastination: Validity and reliability study. International Journal of Social Sciences and Education Research, 1 (2), 584-598.

Tablo 2. Akademik Erteleme Ölçeğinin açıkladığı toplam varyansın tablosu

\begin{tabular}{|c|c|c|c|c|c|c|c|c|c|}
\hline \multirow{2}{*}{ 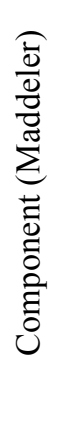 } & \multicolumn{3}{|c|}{$\begin{array}{l}\text { Initial Eigenvalues } \\
\text { (Öz Değerler) }\end{array}$} & \multicolumn{3}{|c|}{$\begin{array}{l}\text { Extraction Sums of Squa- } \\
\text { red Loadings(Karesi Al1- } \\
\text { nan Yüklerin Toplam Ç1- } \\
\text { karımı ) }\end{array}$} & \multicolumn{3}{|c|}{$\begin{array}{l}\text { Rotation Sums of Squared } \\
\text { Loadings (Karesi Alınan } \\
\text { Yüklerin Döndürme Toplamı) }\end{array}$} \\
\hline & 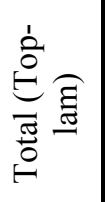 & 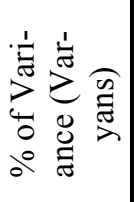 & 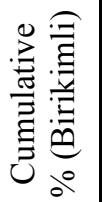 & 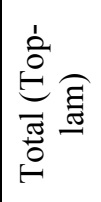 & 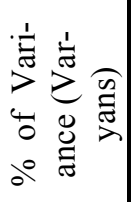 & 叴 & 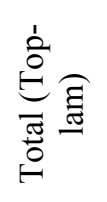 & 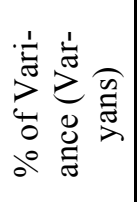 & 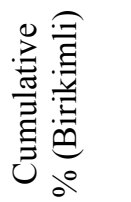 \\
\hline 1 & 13,652 & 35,926 & 35,926 & 13,652 & 35,926 & 35,926 & 9,862 & 25,953 & 25,953 \\
\hline 2 & 3,231 & 8,502 & 44,428 & 3,231 & 8,502 & 44,428 & 5,109 & 13,446 & 39,398 \\
\hline 3 & 1,980 & 5,209 & 49,637 & 1,980 & 5,209 & 49,637 & 3,209 & 8,444 & 47,843 \\
\hline 4 & 1,508 & 3,969 & 53,606 & 1,508 & 3,969 & 53,606 & 2,190 & 5,763 & 53,606 \\
\hline 5 & 1,307 & 3,441 & 57,046 & & & & & & \\
\hline 6 & 1,041 & 2,739 & 59,786 & & & & & & \\
\hline 7 & ,978 & 2,574 & 62,359 & & & & & & \\
\hline 8 & ,926 & 2,437 & 64,796 & & & & & & \\
\hline 9 & 868 & 2,283 & 67,080 & & & & & & \\
\hline 10 & ,789 & 2,076 & 69,156 & & & & & & \\
\hline 11 & ,780 & 2,054 & 71,209 & & & & & & \\
\hline 12 & ,747 & 1,966 & 73,175 & & & & & & \\
\hline 13 & ,731 & 1,923 & 75,099 & & & & & & \\
\hline 14 & 691 & 1,818 & 76,917 & & & & & & \\
\hline 15 & 660 & 1,736 & 78,653 & & & & & & \\
\hline 16 & ,629 & 1,654 & 80,307 & & & & & & \\
\hline 17 & ,573 & 1,508 & 81,815 & & & & & & \\
\hline 18 & 557 & 1,467 & 83,282 & & & & & & \\
\hline 19 & ,509 & 1,339 & 84,620 & & & & & & \\
\hline 20 & ,483 & 1,272 & 85,893 & & & & & & \\
\hline 21 & ,470 & 1,236 & 87,128 & & & & & & \\
\hline 22 & ,432 & 1,137 & 88,265 & & & & & & \\
\hline 23 & ,413 & 1,088 & 89,353 & & & & & & \\
\hline 24 & ,400 & 1,054 & 90,407 & & & & & & \\
\hline 25 & ,384 & 1,010 & 91,417 & & & & & & \\
\hline 26 & 367 & 966 & 92,382 & & & & & & \\
\hline 27 & 354 & ,931 & 93,313 & & & & & & \\
\hline 28 &, 325 & ,856 & 94,170 & & & & & & \\
\hline 29 & ,305 & 802 & 94,972 & & & & & & \\
\hline 30 & 285 & ,749 & 95,721 & & & & & & \\
\hline 31 & ,265 & 697 & 96,418 & & & & & & \\
\hline 32 & ,243 & 639 & 97,057 & & & & & & \\
\hline 33 & 231 & 608 & 97,664 & & & & & & \\
\hline 34 & 210 &, 552 & 98,217 & & & & & & \\
\hline 35 & 203 & ,535 & 98,752 & & & & & & \\
\hline 36 & , 195 &, 514 & 99,266 & & & & & & \\
\hline 37 &, 153 & ,404 & 99,669 & & & & & & \\
\hline 38 & ,126 & ,331 & 100,000 & & & & & & \\
\hline
\end{tabular}

Ancak faktör sayısının fazla olması nedeniyle faktör sayısını azaltmak amacıyla çizgi grafiği incelenmiştir. Bu grafikte 4 ana kırılma noktasının olduğu ve bu kırılma noktalarından sonra eğimin kaybolmaya başladığı görülmektedir. Grafikte eğimin kaybolmaya başladığı noktanın işaret 
Ocak, G., Bulut, R. (2015). Akademik Erteleme Davranışı Ölçeği: Geçerlilik ve güvenirlilik çalışması. International Journal of Social Sciences and Education Research, 1 (2), 584-598.

ettiği bileşen sayısı hesaplanıp faktör sayısı olarak alınmıştır (İlhan, 2007). Ana kırılma noktalarına bağlı olarak ölçek, 4 faktörle sınırlandırılmıştır. Tekrarlayan analizler sonucunda, düşük yük değeri vermeleri nedeniyle üç madde daha (17,23 ve 25$)$ ölçekten çıkarılmıştır.

Faktör analizleri sonucunda, KMO Kaiser-Meyer-Olkin (Örneklem Oluşturma Uygunluğu Ölçümü) değeri .932'ye çıkmış olup 4 faktör toplam varyansın \%53,61'ini açıklamaktadır. KMO değerinin .932 gibi mükemmel bir düzeyde olması, verilerin faktör analizine uygun olduğunun göstergesi olarak yorumlanır (Fidel, 2000; akt:Yurdugül, Belirsiz).

Tablo 3. Akademik Erteleme Ölçeğinin Döndürülmüş Bileşenler tablosu

\begin{tabular}{|c|c|c|c|c|}
\hline \multirow{2}{*}{ Maddeler } & \multicolumn{4}{|c|}{ Component (Bileșenler) } \\
\hline & 1 & 2 & 3 & 4 \\
\hline $\mathrm{m} 18$ & 815 & & & \\
\hline $\mathrm{m} 20$ & ,790 & & & \\
\hline $\mathrm{m} 14$ & ,778 & & & \\
\hline $\mathrm{m} 36$ &, 759 & & & \\
\hline $\mathrm{m} 28$ &, 747 & & & \\
\hline $\mathrm{m} 21$ &, 747 & & & \\
\hline $\mathrm{m} 15$ & 740 & & & \\
\hline m58 & ,732 & & & \\
\hline $\mathrm{m} 32$ &, 720 & & & \\
\hline $\mathrm{m} 27$ &, 720 & & & \\
\hline $\mathrm{m} 53$ & 697 & & & \\
\hline $\mathrm{m} 19$ & 688 & & & \\
\hline $\mathrm{m} 50$ & .616 & & & \\
\hline m39 & 607 & & & \\
\hline $\mathrm{m} 13$ & ,595 & & & \\
\hline m35 & ,559 & & & \\
\hline $\mathrm{m} 4$ &, 545 & & & \\
\hline $\mathrm{m} 30$ & ,539 & & & \\
\hline $\mathrm{m} 2$ &, 516 & & & \\
\hline $\mathrm{m} 67$ & & ,774 & & \\
\hline m59 & & ,720 & & \\
\hline m61 & & ,710 & & \\
\hline $\mathrm{m} 63$ & & ,700 & & \\
\hline m56 & & 660 & & \\
\hline m68 & & 620 & & \\
\hline $\mathrm{m} 49$ & & 617 & & \\
\hline m34 & & ,565 & & \\
\hline $\mathrm{m} 70$ & & ,552 & & \\
\hline m51 & & ,525 & & \\
\hline $\mathrm{m} 73$ & & & ,719 & \\
\hline m66 & & &, 715 & \\
\hline $\mathrm{m} 44$ & & & 652 & \\
\hline m64 & & & 623 & \\
\hline $\mathrm{m} 72$ & & & 613 & \\
\hline $\mathrm{m} 9$ & & & & ,720 \\
\hline $\mathrm{m} 8$ & & & & 673 \\
\hline $\mathrm{m} 16$ & & & & 542 \\
\hline $\mathrm{m} 24$ & & & & ,532 \\
\hline
\end{tabular}

Tablo 3'te verilen döndürülmüş bileşenler tablosuna (Rotated Companent Matrix) göre, 1. faktörde 19 maddenin, 2. faktörde 10 maddenin, 3. faktörde 5 maddenin, 4. faktörde ise 4 maddenin bulunduğu görülmektedir. Ölçekte yer alan 38 maddeye ilişkin faktör yük değerleri 0.52 - 0.82 arasında değişmektedir. 
Ocak, G., Bulut, R. (2015). The Scale of Academic Procrastination: Validity and reliability study. International Journal of Social Sciences and Education Research, 1 (2), 584-598.

Madde analizinde, geçerliliği incelemenin bir başka iç ölçütü de madde düzeyinde, uç grupların (üst grup- alt grup) puan ortalamalarının karşılaştırılmasıdır (Can, 2013; Erkuş, 2014; Özçelik, 2010). Bu durumda ölçeğin geliştirilme aşamasında araştırmaya katılanlardan üst \%27 ve alt \%27'lik grupların her bir maddeye verdikleri cevaplar ilişkisiz t testi ile karşılaştırılmıştır. Yapılan karşılaştırma sonucunda ölçeğe alınacak tüm maddelerin alt ve üst grup farkının anlamlı olduğu tespit edilmiştir.

Tablo 4. Akademik Erteleme Ölçeğinin Sorumsuzluk alt boyutuna ait Geçerlik-Güvenirlik analizi sonuçları

\begin{tabular}{|c|c|c|c|c|c|}
\hline I.Faktör (Sorumsuzluk) & $\begin{array}{l}\text { Varimax } \\
\text { Faktör } \\
\text { Yükü } \\
\end{array}$ & $\begin{array}{l}\text { Madde } \\
\text { Toplam }\end{array}$ & $\begin{array}{c}\text { Madde Kalan } \\
\text { Korelasyonu }\end{array}$ & $\mathbf{t}$ & $\mathbf{P}$ \\
\hline $\begin{array}{l}\text { 18- Daha önemli bir işim olmamasına rağmen } \\
\text { gereksiz yere akademik görevlerimi ertelerim. }\end{array}$ &, 815 & ,791 &, $581^{* *}$ & 15,74 &, 000 \\
\hline $\begin{array}{l}\text { 20- Plansız biri olduğum için akademik gö- } \\
\text { revlerimi yapmayı son anlara kadar ertelerim. }\end{array}$ & ,790 & ,803 &, $622^{* *}$ & 17,86 &, 000 \\
\hline $\begin{array}{l}\text { 14- Gereksiz mazeretlerle sınavlara hazırlan- } \\
\text { mayı son güne kadar geciktiririm. }\end{array}$ & ,778 & ,735 &, $505^{* *}$ & 13,88 &, 000 \\
\hline $\begin{array}{l}\text { 36- Çalışma motivasyonum düşük olduğu için } \\
\text { ödev yapma ve sınavlara hazırlanma gibi gö- } \\
\text { revlerimi yapmayı ertelerim. }\end{array}$ & ,759 & ,802 &, $613^{* *}$ & 15,53 &, 000 \\
\hline $\begin{array}{l}\text { 28- Beni harekete geçirecek güç olmadığ için } \\
\text { akademik görevlerimi yapmayı, başka güne } \\
\text { ertelerim. }\end{array}$ &, 747 & ,761 &, $607^{* *}$ & 15,17 &, 000 \\
\hline $\begin{array}{l}\text { 21- İşlerimi öncelik sırasına göre belirlemedi- } \\
\text { ğim için akademik görevlerimi yapmayı son } \\
\text { güne bırakırım. }\end{array}$ &, 747 & ,766 &, $589^{* *}$ & 17,93 &, 000 \\
\hline $\begin{array}{l}\text { 15- Vicdan azabı çeksem de zamanımın ço- } \\
\text { ğunu ders çalışmak yerine keyif verici aktivi- } \\
\text { telerle geçiririm. }\end{array}$ & ,740 & ,702 &, $519^{* *}$ & 13,65 &, 000 \\
\hline $\begin{array}{l}\text { 58- Yetersiz güdülenmeden dolayı sınavlara } \\
\text { son günlerde çalışırım. }\end{array}$ &, 732 & ,704 &, $544^{* *}$ & 14,39 &, 000 \\
\hline $\begin{array}{l}\text { 32- Akademik görevlerimi yapma isteğim ol- } \\
\text { madığı için onları yapmayı son anlara bırakı- } \\
\text { rım. }\end{array}$ & ,720 & ,769 &, $558^{* *}$ & 14,83 &, 000 \\
\hline $\begin{array}{l}\text { 27-Ödev teslim tarihinin yaklaşmasına rağ- } \\
\text { men ödevlerimi yapma isteğim olmuyor. }\end{array}$ & ,720 &, 748 &, $582^{* *}$ & 15,44 &, 000 \\
\hline $\begin{array}{l}\text { 53- Kendime bu kez ders çalışmaya başlaya- } \\
\text { cağım deyip ancak ders çalışmayan biriyim. }\end{array}$ & 697 & ,678 &, $496^{* *}$ & 12,08 &, 000 \\
\hline 19- Ben bir zaman israfçısıyım. & ,688 & 672 &, $568^{* *}$ & 14,69 &, 000 \\
\hline $\begin{array}{l}\text { 50- Önemli akademik görevlerimi bile son } \\
\text { anlarda yaparım. }\end{array}$ & ,616 & ,629 &, $514^{* *}$ & 15,42 &, 000 \\
\hline $\begin{array}{l}\text { 39- Çokça çaba harcattıran akademik görev- } \\
\text { leri yapmayı, son ana bırakırım. }\end{array}$ & ,607 & ,694 &, $593^{* *}$ & 15,43 &, 000 \\
\hline $\begin{array}{l}\text { 13- Sosyal aktivitelere (film izlemek, gezmek, oyun } \\
\text { oynamak vb.) bolca zaman ayırdığım için akademik } \\
\text { görevlerimi yapmayı son ana bırakırım. }\end{array}$ &, 595 & ,621 & $458^{* *}$ & 11,62 &, 000 \\
\hline $\begin{array}{l}\text { 35- Akademik görevlerimi yapmaya başladı- } \\
\text { ğımda, kendimi motive edemem. }\end{array}$ & ,559 & ,614 &, $475^{* *}$ & 11,68 &, 000 \\
\hline $\begin{array}{l}\text { 4- Sadece ders çalışmaya başlamak bile uzun } \\
\text { zamanımı alır. }\end{array}$ &, 545 &, 539 & $425^{* *}$ & 10,068 &, 000 \\
\hline $\begin{array}{l}\text { 30- Başarısız olma kaygısından dolayı ders } \\
\text { çalışma ya da sınavlara hazırlanma gibi so- } \\
\text { rumluluklarımı yapmayı geciktiririm. }\end{array}$ &, 539 & ,631 &, $459^{* *}$ & 10,58 &, 000 \\
\hline $\begin{array}{l}\text { *2- Akademik görevlere ne kadar zaman ayı- } \\
\text { racağımı önceden planlarım. }\end{array}$ &, 516 &, 526 & $390^{* *}$ & 8,613 & ,000 \\
\hline
\end{tabular}

*Tersten puanlanan maddeler 
Ocak, G., Bulut, R. (2015). Akademik Erteleme Davranışı Ölçeği: Geçerlilik ve güvenirlilik çalışması. International Journal of Social Sciences and Education Research, 1 (2), 584-598.

Yapılan analizler sonucunda ölçeğin dört faktörlü olduğu ve bu durumun ölçeğin hazırlanmasında dikkate alınan akademik erteleme davranışı ölçeğinin dört temel yapıyı (akademik mükemmeliyetçilik, akademik görevin algılanan niteliği, öğretmenlere ilişkin olumsuz alg1 ve sorumsuzluk) yansıttığ düşünülmüştür. Bu araştırmada akademik mükemmeliyetçilik, bir görevi mükemmel bir şekilde yapma düşüncesiyle verilen görev üzerinde gereğinden fazla zaman harcama anlamında; akademik görevin algılanan niteliği, verilen bir akademik görevin öğrenciler tarafından kolay-zor, ilgi çekici-sıkıcı ve uzun-kısa gibi olumlu veya olumsuz sıfatlarla nitelemelerini ifade etmeleri anlamında; öğretmenlere ilişkin olumsuz algı ise, öğrencilerin öğretmenlere ilişkin olumsuz düşüncelerinin akademik görevlerini yapma davranışları üzerindeki etkisi anlamında kullanılmıştır. Son olarak sorumsuzluk alt boyutu ise öğrencilerin akademik görevleri yapamaya istekli olmamaları ve bunun için gerekli zamanı ayırmamaları anlamında kullanılmıştır. Tüm kriterler göz önünde bulundurularak yapılan değerlendirme sonucunda 75 maddelik deneme ölçeğinin 37 maddesi ölçekten çıkarılmış ve ölçekte 38 madde kalmıştır. Yapılan analizler sonucunda faktör yük değerlerinin, dört faktör için de .52 ile .82 arasında değiştiği görülmektedir. Ölçeğin her bir alt faktör için madde toplam korelâsyonları I. faktör için .803 - .526; II. faktör için 677- .492; III. faktör için .678- .502; IV. faktör için ise .481-.378 arasında değiştiği tespit edilmiştir.

Tablo 4'e görüldüğü gibi sorumluluk alt boyutunda 19 madde yer almaktadır. Maddelerin faktör yük değerleri ,516- ,815 arasında değişmektedir. Sorumsuzluk alt boyutunda yer alan tüm maddeler için t değerinin anlamlı olduğu görülmektedir.

Tablo 5. Akademik Erteleme Ölçeğinin Akademik Görevin Algılanan Niteliği alt boyutuna ait Geçerlik-Güvenirlik analizi sonuçları

\begin{tabular}{|c|c|c|c|c|c|}
\hline $\begin{array}{c}\text { II. Faktör (Akademik görevin algılanan } \\
\text { niteliği) }\end{array}$ & $\begin{array}{l}\text { Varimax } \\
\text { Faktör } \\
\text { Yükü }\end{array}$ & $\begin{array}{l}\text { Madde } \\
\text { Toplam }\end{array}$ & $\begin{array}{l}\text { Madde Ka- } \\
\text { lan Korelas- } \\
\text { yonu }\end{array}$ & $\mathbf{t}$ & $\mathbf{P}$ \\
\hline $\begin{array}{l}\text { *67-İlgimi çeken akademik görevleri, za- } \\
\text { manında yaparım. }\end{array}$ & ,774 & 673 &, $262^{* *}$ & 7,75 &, 000 \\
\hline $\begin{array}{l}\text { *59- Ödevlerimi zamanında teslim etmek } \\
\text { için gerekli azmi gösteririm. }\end{array}$ & ,720 & 677 &, $373^{* *}$ & 9,02 & ,000 \\
\hline $\begin{array}{l}\text { *61- Yaparken zevk alacağım akademik } \\
\text { görevleri, hemen yaparım. }\end{array}$ & ,710 & 658 &, $384^{* *}$ & 9,62 &, 000 \\
\hline $\begin{array}{l}\text { *63- Eğer verilen ödevlerin yapılması } \\
\text { zevkli ise, hemen yapmaya başlarım. }\end{array}$ & ,700 & ,601 &, $310^{* *}$ & 6,91 & ,000 \\
\hline $\begin{array}{l}\text { *56- Üstesinden gelebileceğim dersleri } \\
\text { zamanında yaparım. }\end{array}$ & 660 & ,606 &, $389^{* *}$ & 8,03 &, 000 \\
\hline $\begin{array}{l}\text { *68- Beni çok uğraştıracak olsa bile aka- } \\
\text { demik görevlerimi zamanında yaparım. }\end{array}$ & 620 & 628 &, $462^{* *}$ & 10,6 &, 000 \\
\hline $\begin{array}{l}\text { *49-Yapılması kolay olan akademik gö- } \\
\text { revleri hemen yapıp aradan çıarırım. }\end{array}$ & ,617 & ,499 &, $357^{* *}$ & 7,35 &, 000 \\
\hline $\begin{array}{l}\text { *34-Uzun zaman alacak ödevleri, hemen } \\
\text { yapmaya başlarım. }\end{array}$ & ,565 & ,500 &, $280^{* *}$ & 7,87 & ,000 \\
\hline $\begin{array}{l}\text { *70-Verilen akademik görevler zor da } \\
\text { olsa zamanında yaparım. }\end{array}$ & ,552 &, 521 &, $347^{* *}$ & 8,02 &, 000 \\
\hline $\begin{array}{l}\text { *51- Üzerinde düşünmeye sevk eden aka- } \\
\text { demik görevleri sevdiğim için onları za- } \\
\text { manında yaparım. }\end{array}$ & ,525 & ,492 &, $300^{* *}$ & 6,77 & ,000 \\
\hline
\end{tabular}

*Tersten puanlanan maddeler

Tablo 5'te verilen bilgilere göre, akademik görevin algılanan niteliği alt boyutunda, 10 madde yer almaktadır. Maddelerin faktör yük değerleri ,525-,774 arasında değişmektedir. Akademik 
Ocak, G., Bulut, R. (2015). The Scale of Academic Procrastination: Validity and reliability study. International Journal of Social Sciences and Education Research, 1 (2), 584-598.

görevin algılanan niteliği alt boyutunda yer alan tüm maddeler için $t$ değerinin anlamlı olduğu görülmektedir.

Tablo 6. Akademik Erteleme Ölçeğinin Öğretmenlere İlişkin Olumsuz Alg1 alt boyutuna ait Geçerlik-Güvenirlik analizi sonuçları

\begin{tabular}{|l|c|c|c|c|c|}
\hline III.Faktör (Öğretmenlere İlişkin olumsuz algı) & $\begin{array}{c}\text { Varimax } \\
\text { Faktör } \\
\text { Yükü }\end{array}$ & $\begin{array}{c}\text { Madde } \\
\text { Toplam }\end{array}$ & $\begin{array}{c}\text { Madde Kalan } \\
\text { Korelsyonu }\end{array}$ & t & P \\
\hline $\begin{array}{l}\text { 73- Dersine gereken önemi vermeyen öğretmenin } \\
\text { verdiği ödevleri yapmayı son ana kadar ertelerim. }\end{array}$ &, 719 &, 678 &, $373^{* *}$ & 11,40 &, 000 \\
\hline $\begin{array}{l}\text { 66- Öğrenciye bir şeyler kazandırmak yerine dersi } \\
\text { boş geçirmeye çalı̧an hocaların verdiği ödevleri } \\
\text { yapmayı son güne kadar ertelerim. }\end{array}$ &, 715 &, 514 &, $300^{* *}$ & 7,65 &, 000 \\
\hline $\begin{array}{l}\text { 44-Bana bir şeyler kazandıramayacağını düşündü- } \\
\text { ğüm öğretmenin verdiği akademik görevleri, yap- } \\
\text { mayı ertelerim. }\end{array}$ &, 652 &, 531 &, $280^{* *}$ & 7,19 &, 000 \\
\hline $\begin{array}{l}\text { 64-Baskıcı öğretmenlerin verdiği akademik görev- } \\
\text { leri yapmayı ertelerim. }\end{array}$ &, 623 &, 529 &, $357^{* *}$ & 9,96 &, 000 \\
\hline $\begin{array}{l}\text { 72-Sevmediğim öğretmenlerin ödevlerini, zama- } \\
\text { nında yapmam. }\end{array}$ &, 613 &, 502 &, $389^{* *}$ & 9,54 &, 000 \\
\hline
\end{tabular}

Tablo 6'da görüldüğü gibi öğretmenlere ilişkin olumsuz alg1 alt boyutunda 5 madde yer almaktadır. Maddelerin faktör yük değerleri ,613-,719 arasında değişmektedir. Öğretmenlere ilişkin olumsuz algı alt boyutunda yer alan tüm maddeler için $t$ değerinin anlamlı olduğu görülmektedir.

Tablo 7. Akademik Erteleme Ölçeğinin Akademik Mükemmeliyetçilik alt boyutuna ait Geçerlik-Güvenirlik analizi sonuçları

\begin{tabular}{|l|c|c|c|c|c|}
\hline IV.Faktör (Akademik Mükemmeliyetçilik) & $\begin{array}{c}\text { Varimax } \\
\text { Faktör } \\
\text { Yükü }\end{array}$ & $\begin{array}{c}\text { Madde } \\
\text { Toplam }\end{array}$ & $\begin{array}{c}\text { Madde Ka- } \\
\text { lan Kore- } \\
\text { las- } \\
\text { yonu }\end{array}$ & t & P \\
\hline $\begin{array}{l}\text { 9-Ödevlerim üzerinde tekrar tekrar düzeltmeler } \\
\text { yaptığım için ödevlerimi zamanında yetiştire- } \\
\text { meme riskim olmuştur. }\end{array}$ &, 720 &, 479 &, $216^{* *}$ & 5,35 &, 000 \\
\hline $\begin{array}{l}\text { 8-Sınava hazırlanırken çalıştığım yerleri tekrar } \\
\text { tekrar çalışmaktan dolayı diğer sınavlara hazır- } \\
\text { lanmakta gecikirim. }\end{array}$ &, 673 &, 356 &, $169^{* *}$ & 4,93 &, 000 \\
\hline $\begin{array}{l}\text { 16-Ödevlerimi en iyi şekilde yapayım derken, } \\
\text { ödevleri bitirmeyi son güne kadar geciktiririm. }\end{array}$ &, 542 &, 481 &, $400^{* *}$ & 8,73 &, 000 \\
\hline $\begin{array}{l}\text { 24-En iyisini, en güzelini yapma düşüncesi bile } \\
\text { ders çalışmaya başlamamı geciktirir. }\end{array}$ &, 532 &, 378 &, $219^{* *}$ & 4,03 &, 000 \\
\hline
\end{tabular}

Tablo 7'de verilen bilgilere göre, akademik mükemmeliyetçilik alt boyutunda, 4 madde yer almaktadır. Bu alt boyutta yer alan maddelerin faktör yük değerleri ,532-,720 arasında değişmektedir. Akademik mükemmeliyetçilik alt boyutunda yer alan tüm maddeler için $t$ değerlerinin anlamlı olduğu görülmektedir. 
Ocak, G., Bulut, R. (2015). Akademik Erteleme Davranışı Ölçeği: Geçerlilik ve güvenirlilik çalışması. International Journal of Social Sciences and Education Research, 1 (2), 584-598.

Tablo 8. Akademik Erteleme Ölçeğinin alt faktörlerinin açıkladığı varyans oranları ve İç Tutarlılık katsayıları

\begin{tabular}{|l|c|c|}
\hline \multicolumn{1}{|c|}{ Faktörler } & Açıkladı̆̆ı Varyans & Alfa \\
\hline 1. Sorumsuzluk & 25,95 &, 951 \\
\hline 2.Akademik Görevin Algılanan Niteliği & 13,45 &, 866 \\
\hline 3.Öğretmenleri İlişkin Olumsuz Algı & 8,44 &, 777 \\
\hline 4. Akademik Mükemmeliyetçilik & 5,76 &, 640 \\
\hline Toplam & 53,61 &, 947 \\
\hline
\end{tabular}

Tablo 8 'de verilen bilgilere göre, her bir faktörün açıkladıkları varyans oranı sırasıyla $\% 25.95$, $\% 13.45, \%$ 8.44, \% 5,76 ve faktörlerin tamamının açıkladığı toplam varyans 53,61'dir. I. faktör (sorumsuzluk) için alfa katsayısı. ,951 iken, aynı katsayı II. faktör (akademik görevin niteliği) için ,866, III. faktör (öğretmenleri ilişkin olumsuz alg1) için .777, IV. faktör (akademik mükemmeliyetçilik) için ise .640 'dur. Ölçeğin toplam alfa değeri ise $\alpha=0.947$ 'dir.

\section{Sonuç ve tartışma}

$\mathrm{Bu}$ çalışmada, öğretmen adaylarının akademik erteleme davranışlarını belirlemek amacıyla geçerli ve güvenilir bir ölçme aracı hazırlanması amaçlanmıştır. Başlangıçta 80 maddeden oluşan deneme ölçeğinin 381 öğretmen adayına uygulanmasından sonra yapılan analizler sonucunda, ölçekten 37 madde çıkartılmıştır. Sonuç olarak ölçekte, 11'i olumsuz 27'si olumlu olmak üzere toplam 38 madde kalmıştır. Bu maddelerin ölçeğin hazırlanmasında dikkate alınan dört temel yapıyı (sorumsuzluk, akademik görevin algılanan niteliği, öğretmenlere ilişkin olumsuz algı, akademik mükemmeliyetçilik) yansıttığı görülmüştür. Yapılan analizler sonucunda faktör yük değerlerinin, dört faktör için de ,516 -,815 arasında değiştiği tespit edilmiştir.

I. Faktörde yer alan $(18,20,14,21,28,36,27,15,58,32,19,53,39,13,4,2,30,35,50)$ maddelere baktığımızda akademik erteleme davranışı ile ilgili sorumsuzluğu ölçmektedir. II. faktörde yer alan $(67,59,61,63,56,49,68,70,34,51)$ maddelerin akademik görevin algilanan niteliğini, III. faktörde yer alan (73, 66, 72, 44, 64 ) maddelerin öğretmenlere ilişkin olumsuz algıyı ve son olarak IV. faktörde yer alan $(8,9,24,16)$ maddelerin akademik mükemmeliyetçiliği ölçtüğü tespit edilmiştir.

Akademik erteleme davranışı ölçeğiyle ilgili korelasyon katsayıları incelendiğinde, maddeler arasında pozitif yönde, anlamlı ve genellikle orta ve yüksek düzeyde bir ilişkinin olduğu görülmektedir. Bir ölçekte yer alan maddelerin korelasyon katsayılarının yüksek olması, ölçeğin iç tutarlılığının yüksek olduğunu gösterir (DeVellis, 2014). Dört faktörlü olarak saptanan ölçeğin her bir alt faktörü için madde toplam korelâsyon katsayıları I. faktör için .803 - .526; II. faktör için 677- .492; III. faktör için .678- .502; IV. faktör için ise .481-.378 arasında değiş̧mektedir.

Elde edilen faktörlerin güvenirlik durumuna bakıldığında; I. faktör (sorumsuzluk) için alfa katsayısı 951 iken, aynı katsayı II. faktör (akademik görevin algılanan niteliği) için .866, III. faktör (öğretmenlere ilişkin olumsuz alg1) için .777, IV. faktör (akademik mükemmeliyetçilik) için ise .640 'tır. Ölçeğin toplam alfa katsayı değeri ise $\alpha=0.947$ 'dir. Alfa katsayısının değerlendirilmesinde kullanılan ölçütlere göre, 90 üstünde bir alfa katsayısına sahip bir ölçeğin, yüksek derecede güvenilir olduğu söylenebilir (Özdamar,1999:522; akt: Tavşanc11, 2010:29). Bu ölçüt 
Ocak, G., Bulut, R. (2015). The Scale of Academic Procrastination: Validity and reliability study. International Journal of Social Sciences and Education Research, 1 (2), 584-598.

göz önünde bulundurulduğunda, akademik erteleme davranışını ölçmeye yönelik geliştirilen ölçeğin yüksek derecede güvenilir bir ölçme aracı olduğu söylenebilir.

“Akademik Erteleme Davranışını Etkileyen Faktörler Ölçeği”ne ilişkin yapılan geçerlilik ve güvenirlik analizleri sonucunda, öğretmen adaylarının akademik erteleme davranışlarını ölçen dört faktörlü ölçeğin, geçerli ve güvenilir bir ölçme aracı olduğu kabul edilebilir. Buna göre, araştırmaya konu edilen ölçek faktör dağılımları ve geçerlik-güvenirlik değerleri açısından kullanılabilecek bir yapıda olmakla birlikte ölçeğin yeni yapılacak çalışmalarda da geçerlilik ve güvenirlik analizlerinin yapılması ölçeğin geliştirilmesine katkı sağlayacağı düşünülmektedir.

\section{Kaynakça}

Alay, S. ve Koçak, S. (2002). Zaman Yönetimi Anketi: Geçerlilik ve Güvenirlilik. Hacettepe Üniversitesi Eğitim Fakültesi Dergi. 22, 9-13.

Balkıs, M. (2007). Öğretmen Adaylarının Davranışlarındaki Erteleme Eğiliminin, Karar Verme Stilleri ile İlişkisi. Pamukkale Üniversitesi Eğitim Fakültesi Dergisi, 1(21), 67-83.

Büyüköztürk, Ş. (2002). Faktör Analizi: Temel Kavramlar ve Ölçek Geliştirmede Kullanımı. Kuram ve Uygulamada Eğitim Yönetimi Dergisi, (32), 470-483.

Büyüköztürk, Ş. (2012). Sosyal Bilimler için Veri Analizi El Kitabı. (16. Baskı). Ankara: Pegem Akademi.

Binder, K. (2000). The Effect of an Academic Procrastination Treatment on Student Procrastination and Subjective Well-Being. (Unpublished MA). Carleton University, Canada.

Can, A. (2013). SPSS ile Bilimsel Araştırma Sürecinde Nicel Veri Analizi. Ankara: Pegem Akademi.

Chun, A. H. C. \& Choi, J. N. (2005). Rethinking Procrastination: Positive Effects of "Active" Procrastination Behavior on Attitudes and Performance. The Journal of Social Psychology, 145(3), 245-264.

Çakıcı, D. C. (2003). Lise ve Üniversite Öğrencilerinde Genel Erteleme ve Akademik Erteleme Davranışlnın İncelenmesi. (Yayınlanmamış Yüksek Lisans Tezi). Ankara Üniversitesi, Ankara.

DeVellis, F. R.(2014). Scale Development Theory and Application (M.Uluman Çev.). Ankara: Nobel Yayincilik.

Ellez, M.(2012). Ölçme Araçlarında Bulunması Gereken Özellikler. (A. Tanrı̈ğgn Ed.),

Bilimsel Araştırma Yöntemleri. Ankara: Anı Yayıncılık.

Erkuş, A. (2014). Psikolojide Ölçme ve Ölçek Geliştirme -I (2. Baskı). Ankara: Pegem Akademi

Ferrari, J. R. \& Pychyl, T. A. (Eds.) (2000). The Scientific Study of Procrastination: Where Have We Been and Where Are We Going? Journal of Social Behavior And Personality (Special Issue), 15, vii-viii.

İlhan, F. (2007). Faktör Analizi ve Tarımsal Araştırmalarda Elde Edilen Verilere Uygulanması Üzerine Bir Çalışma. Selçuk Üniversitesi, Yayımlanmış yüksek lisans tezi, Konya.

Karagöz, Y. ve Ekici, S.(2004). Sosyal Bilimlerde Yapılan Uygulamalı Araştırmalarda Kullanılan İstatistiksel Teknikler Ve Ölçekler. C.Ü. İktisadi ve İdari Bilimler Dergisi, 5 (1), 25-43.

Karasar, N.(2013). Bilimsel Araştırma Yöntemi (25. Bask1). Ankara: Nobel Yayınları.

Kennedy, G. J \& Tuckman, B. W. (2013). An Exploration into the İnfluence of Academic and Social Values, Procrastination, and Perceived School Belongingness on Academic Performance. Social Psychology Education, 16, 435-470. DOI 10.1007/s11218-013-9220-z

Özbay, Y. ve Mısırl1-Taşdemir, Ö. (2003). Çok Boyutlu Mükemmeliyetçilik Ölçeği: Geçerlik ve Güvenirlik Çalışması. VII. Ulusal Psikolojik Danışma ve Rehberlik Kongresi, 9-11 Temmuz, Malatya. 
Ocak, G., Bulut, R. (2015). Akademik Erteleme Davranışı Ölçeği: Geçerlilik ve güvenirlilik çalışması. International Journal of Social Sciences and Education Research, 1 (2), 584-598.

Özçelik, D. A.(2010). Test Hazırlama Kılavuzu (4. Baskı). Ankara: Pegem Akademi.

Polat, Y.(2012). Faktör Analizi Yöntemlerinin Karşılaştırmalı Olarak Incelenmesi ve Hayvancılık Denemesine Uygulanışı. Çukurova Üniversitesi Fen Bilimleri Enstitüsü, Adana.

Saraçl1, S. (2011). Faktör Analizinde Yer Alan Döndürme Metotlarının Karşılaştırmalı İncelenmesi Üzerine Bir Uygulama. Düzce Üniversitesi Sağllk Bilimleri Enstitüsü Dergisi, 1(3): 22-26

Senecal, C., Koestner, R., \& Vallerand, R. J. (1995). Self-regulation and academic procrastination. The Journal of Social Psychology, 135(5), 607-619.

Stevenson, A. (2013). Oxford Dictionarty of English. (3. Bask1 ) http://www.oxfordreference.com/view/10.1093/acref/9780199571123.001.0001/m en gb0988120?rskey=MP0X8Q\&re$\underline{\text { sult }=3}$ Erşim tarihi:10.12.2014

Tavşancıl, E.(2010). Tutumların Ölçülmesi ve SPSS ile Veri Analizi. Ankara: Nobel Yayın Dağıtım.

Tekindal, S. (2009). Duyuşsal Özelliklerin Ölçülmesi Için Araç Oluşturma (Baskı 2). Ankara: Pegem Yay1nlar1.

Temel, A. (2010). Eğitimde Ölçme ve Değerlendirme, http://cihangoc.com/wp-content/uploads/2013/03/2EOD.kitap .doc Erişim Tarihi: 08.10.2014

Türk Dil Kurumu; Türkçe Sözlük, Türk Dil Kurumu Yayınları, Ankara, 2011.

Vestervelt, C. M. (2000). An Examination of the Content and Construct Validity of Four Measures of Procrastination. (Unpublished MA). Carleton University, Canada.

Yurdugül, H. Faktör analizinde KMO ve Bartlett Testleri Neyi Ölçer? http://yunus.hacettepe.edu.tr/ yurdugul/3/indir/Kuresellik.pdf Erişim Tarihi: 11.07.2015 
Ocak, G., Bulut, R. (2015). The Scale of Academic Procrastination: Validity and reliability study. International

Journal of Social Sciences and Education Research, 1 (2), 584-598.

\section{Extended abstract in English}

In academic life, students' attitudes towards the duties may cause them to fulfill these duties or delay them. There are various factors which cause students to delay these academic duties. It is aimed to develop a scale which includes these factors which effect the academic delay behaviour by taking into consideration the related studies in order to find out these factors. In this research, general survey model has been used. The study group of this research is composed of the teacher candidates who study at departments of Social Studies, Primary School Teaching and Preschool Teaching at Afyon Kocatepe University in 2014-2015 academic year fall semester. 261 $(68,5 \%)$ teacher candidates who participated in this research are girls and $120(31,5 \%)$ teacher candidates who participated in this research are boys. Teacher candidates fom all levels of classes were included in this research. In order to compose the items pool, firstly the researches about academic delay were examined.

The next step was to direct four open ended questions about academic delay to the eight teacher candidates who have similar characteristics with the other teacher candidates to whom the scale would be applied. The key concepts were composed and they were based on the answers of the questions directed at teacher candidates and the results of the literature review. Also, the items pool was composed by the items that were written within the frame of the key concepts. After composing the items pool, the pilot scale whic consisted 75 items was applied to 381 teacher candidates. As the result of the analyses made, 37 items were excluded frm the scale. As a result, 11 negative and 27 positive items remained in the scale. It was seen that these items reflected the four basic structures (irresponsibility, the perceived characteristic of the academic duty, the negative perception towards teachers, academic perfectionism) which were taken into account during the preparation process of the scale.

As a result of the analyses made, it was ascertained that the factor loads of the four factors vary between ,516-,815. The items total correlation coefficiencies of the each sub-factors of the four factor scale vary between as $.803-.526$ for the first factor; .677- .492 for the second factor; $.678-.502$ for the third factor; $.481-.378$ for the fourth factor. When the reliability situation of the factors are examined; whereas the alpha coefficient is .951 for the first factor (irresponsibility), the same coefficient is .866 for the second factor (the perceived characteristic of the academic duty), .777 for the third factor (the negative perception towards teachers) and .640 for the fourth factor (academic perfectionism). The total alpha coefficiency of the scale is $\alpha=0.947$. As a result of the validity and reliability analyses that were made related to "The Factors That Affect Academic Delay Behaviour Scale", the four factor scale which measure the academic delay behaviours of teacher candidates can be regarded as a valid and reliable instrument. According to this, the scale which is the subject of this research is in a form that can be used in terms of the distribution of the factors and the validity-reliability values. However, it is assumed that making the validity and reliability analyses of the scale can contribute to the development of the scale. 
Ocak, G., Bulut, R. (2015). Akademik Erteleme Davranışı Ölçeği: Geçerlilik ve güvenirlilik çalışması. International Journal of Social Sciences and Education Research, 1 (2), 584-598.

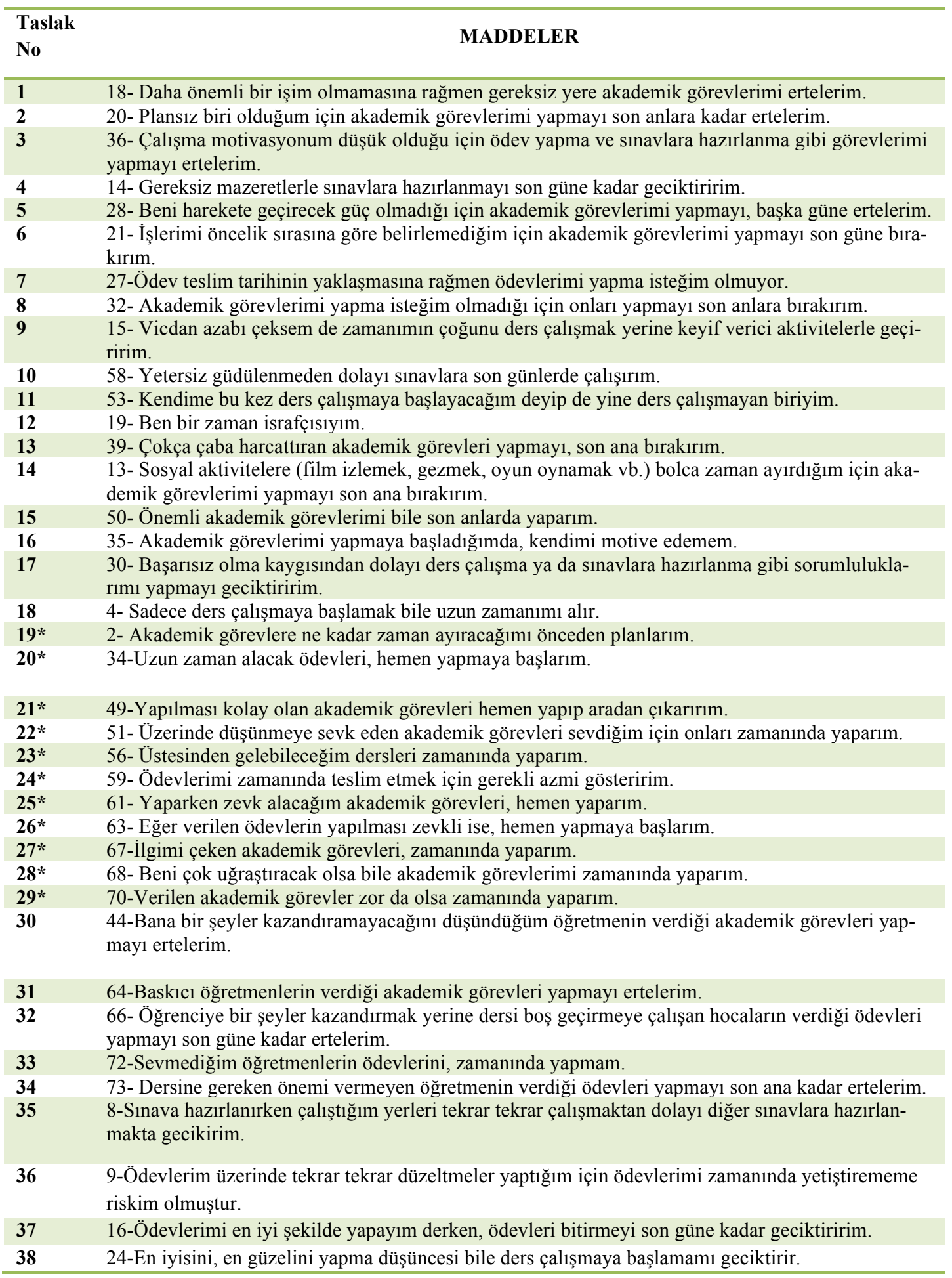

*Tersten puanlanması gereken maddeler 